\title{
A Case of Unilateral Pityriasis Rosea
}

\author{
Gülhan Gürel ${ }^{1 *}$, Vugar Ali Türksoy ${ }^{2}$, Seda Sabah ${ }^{3}$, Sevinç Şahin ${ }^{4}$ and Emine Çölgeçen ${ }^{1}$ \\ ${ }^{1}$ Department of Dermatology,Bozok University School of Medicine, Turkey \\ ${ }^{2}$ Department of Public Health, Bozok University School of Medicine, Turkey \\ ${ }^{3}$ Department of Medical Biology,Bozok University School of Medicine, Turkey \\ ${ }^{4}$ Department of Pathology, Bozok University School of Medicine, Turkey
}

Submission: June 22, 2018; Published: July 05, 2018

*Corresponding author: Gülhan Gürel, Department of Dermatology, Medical Faculty, Bozok University,66200 Yozgat,Turkey, Tel: 90-354-2127060; Fax: 90-354-2177150; Email: gulhanozturkgurel@hotmail.com

\begin{abstract}
Pityriasis rosea (PR) is an acute, self-limited disease, characterized by squamous maculopapular lesions on the trunk and proximal extremities. Unilateral PR is an extremely rare form reported in both children and adult in which the lesions are located on one side of the body. A 50-year-old female patient was admitted to our clinic with multiple red, scaly, asymptomatic lesions over the left side of the trunk and abdomen. Viral DNA isolation was performed by extraction of nucleic acid from serum. Pathogen-specific primer was used to detect DNA from HHV-6 using real-time polymerase chain reaction (PCR) (Bosphore HHV-6 Detection Kit v1). HHV-6 DNA was negative in serum for our patient. The structure of organic tissue and various structures were seen but the consuetudinary image of herpes virus was not found. This case is presented due to its rarity in clinical practice. Further studies of possible triggers for virus activation on an unilateral side of the body in acute PR are needed in order to elucidate the pathophysiology involved.
\end{abstract}

Keywords: Electron microscope; Human Herpes Virus;Pityriasis rosea;Unilateral

\section{Introduction}

Pityriasis rosea (PR) is an acute, self-limited disease, characterized by squamous maculopapular lesions on the trunk and proximal extremities [1]. Although viral agents, autoimmunity, drugs and psychogenic status have been proposed as possible etiological factors, the exact cause is uncertain [2]. Recent studies have determined causal role for systemic active Human Herpes Virus-6 (HHV-6) and Human Herpes Virus-7 (HHV-7) infection in the pathogenesis of PR. These studies have detected HHV-6 and HHV-7 DNA in plasma, HHV-6 and HHV7 mRNA expression and specific antigens in skin lesions of patients with PR [3-5]. Herpes virus virions have also detected by electron microscopy in skin lesions in patients with PR [6].

Atypical forms of PR account for $20 \%$ of all cases[1]. Atypical types can be distinguished by size, distribution, sites involved, severity, the cause of the lesions and morphology, and the unilateral form of PR is very rare [7].

We describe a case of 50-year-old female patient with unilateral PR.

\section{Case Report}

A 50-year-old female patient was admitted to our clinic with multiple red, scaly, asymptomatic lesions over the left side of the trunk and abdomen. The lesions had appeared over a period of 10 days and then remained unchanged. The patient described no prodromal symptoms. Her medical history was not remarkable for any disease or medication use. System examination revealed no pathological finding. Dermatological examination revealed multiple annular, erythematous plaques with a peripheral collarette of scales on the left side of the trunk and abdomen (Figure 1). Laboratory test results were within normal limits. The clinical appearance of the lesions was compatible with unilateral PR. A punch biopsy was performed from a lesion. Light microscopic examination revealed parakeratosis and small microabscesses containing neutrophil leukocytes in the keratin layer. Epidermis was characterized by irregular psoriasiform hyperplasia, focal spongiosis, mild lymphocyte exocytosis and partially diminution of the granular layer. Mild edema, infrequent melanophages, extravasated erythrocytes 
and mild perivascular lymphocytic infiltration containing some eosinophils and neutrophils were observed in the superficial dermis (Figures 2\&3).
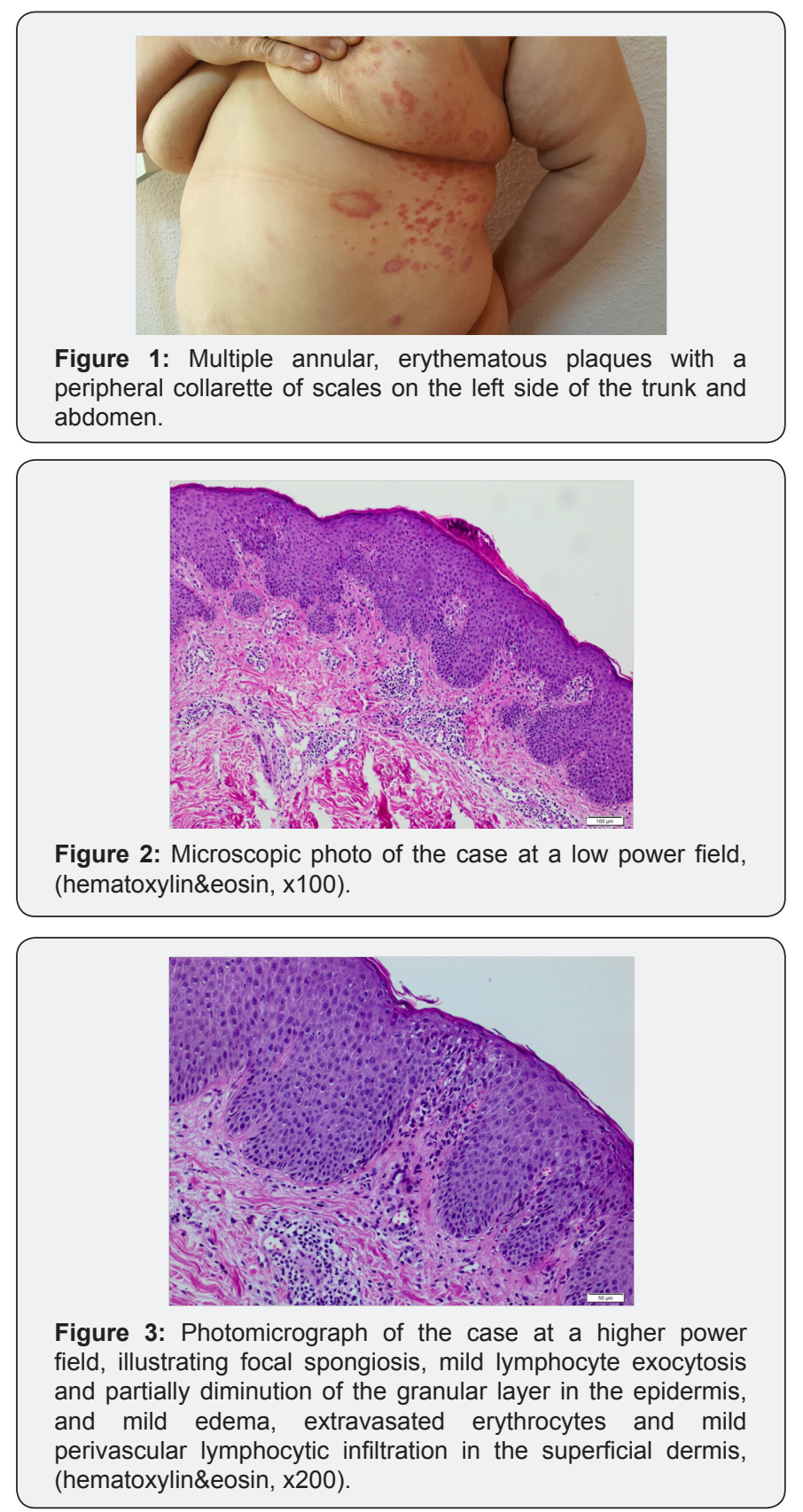

Viral DNA isolation was performed by extraction of nucleic acid from serum. Pathogen-specific primer was used to detect DNA from HHV-6 using real-time polymerase chain reaction (PCR) (Bosphore HHV-6 Detection Kit v1). HHV-6 DNA was negative in serum for our patient.

The texture was analyzed with a Field Emission-Environmental Scanning Electron Microscope-Energy Distribution Spectrometer (FE-ESEM-EDS) (FEI, Quanta FEG 450). The tissue sample was placed on the platform and fixed. Subsequently, imaging analysis of the sample was performed as either low or high vacuum in various sizes (100x, 50x, 10x, 2x, 1x) (Figure 4). As a result of the examination, it was seen that the structure of organic tissue and various structures were seen but the consuetudinary image of herpes virus was not found.
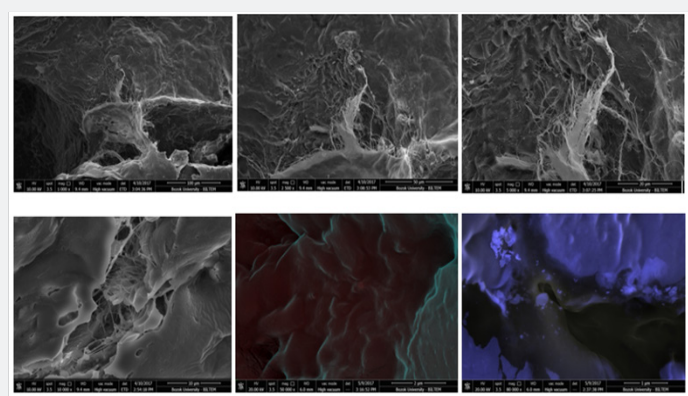

Figure 4: The image of the tissue sample with FE-ESEM-EDS in various sizes (100x, 50x, 10x, 2x, 1x).

The patient was diagnosed with unilateral PR based on the clinical and histopathological findings. She was treated with topical corticosteroids and oral antihistamines and the lesions healed completely within 6 weeks.

\section{Discussion}

There are several clinical and morphological variants of PR, including vesicular, purpuric, urticarial, generalized papular, lichenoid lesions, erythema multiforme-like lesions, follicular, gigantic plaques and even exfoliative dermatitis [2]. Lesions may also present in an atypical site or distribution such as inverse, acral, unilateral, blaschkoid pattern, limb-girdle, oral mucosa and localized $[2,8,9]$. Unilateral PR is an extremely rare form reported in both children and adult in which the lesions are located on one side of the body [9]. Our patient's lesions remained unilateral and no new lesions developed at follow-up.

While the etiology remains uncertain, several clinical and epidemiologic features suggest that a viral infectious agent is involved in the pathogenesis [10]. Drago et al first implicated HHV-7 reactivation in the etiology of PR in 1997 [11]. However, Kempf et al reported no association between HHV-7 and PR [12]. Yasukowa et al showed a possible link between HHV-6 reactivation and PR [13]. Watanabe et al detected HHV-7 and/or HHV-6 DNA in lesional skin, nonlesional skin, saliva, peripheral blood mononuclear cells and serum samples in most nonlesional patients with PR using nested PCR [5]. Karabulut et al detected HHV-7 DNA in 28\% of tissue samples from 21 patients with PR but from none of the 7 control subjects their data did not support the involvement of HHV-7 in the etiology of PR [14].

Drago et al detected herpes virus virions in various stages of morphogenesis by electron microscopy in skin specimens and in cocultured peripheral blood mononuclear cells from acute PR patients $[4,6]$. In this case, the structure of organic tissue and various other structures were seen, but the usual image of herpes virus was not observed. 


\section{Conclusion}

Although we failed to confirm a possible role of human herpes viruses in the pathogenesis of $P R$, previous studies have indicated a possible role for HHV-6, and especially HHV-7 in acute PR. This case is presented due to its rarity in clinical practice. Further studies of possible triggers for virus activation on an unilateral side of the body in acute PR are needed in order to elucidate the pathophysiology involved.

\section{References}

1. Kilinc F, Akbas A, Sener S, Aktaș A (2017) Atypical pityriasis rosea: clinical evaluation of 27 patients. Cutan Ocul Toxicol36(2):157-162.

2. Mahajan K, Relhan V, Relhan AK, Garg VK (2016) Pityriasis Rosea: An Update on Etiopathogenesis and Management of Difficult Aspects. Indian J Dermatol 61(4):375-384.

3. Drago F, Rebora A (2003) Viral reactivation and skin eruptions, Dermatology 207:1-2.

4. Drago F, Ranieri E, Malaguti F, Battifoglio ML, Losi E, et al. (1997) Human herpesvirus7 in patients with pityriasis rosea. Electron microscopy investigations and polymerasechain reaction in mononuclear cells, plasma and skin. Dermatology 195(4):374-378.

5. Watanabe T, Kawamura T, Jacob SE, Aquilino EA, Orenstein JM, et al (2002) Pityriasis rosea is associated with systemic active infection with both human herpesvirus-7 and human herpesvirus-6. J Invest Dermatol 119(4):793-797.
6. Drago F, Malaguti F, Ranieri E, Losi E, Rebora A (2002) Human herpes virus-like particles in pityriasis rosea lesions: an electron microscopy study. J Cutan Pathol 29(6): 359-361.

7. Badakhsh H, Fadaei F, Badakhsh M, Balouchi A (2016) Atypical Pityriasis Rosea with Unilateral Presentation. J Clin Diagn Res 10(12):WD01-WD02.

8. Brar BK, Pall A, Gupta RR (2003) Pityriasis rosea unilateralis. Indian I Dermatol Venereol Leprol 69(1):42-43.

9. Zawar V (2010) Unilateral pityriasis rosea in a child. J Dermatol Case Rep 4(4):54-56.

10. Osawa A, Haruna K, Okumura K, Taneda K, Mizuno Y, et al. (2011) Pityriasis rosea showing unilateral localization. J Dermatol 38(6):607609.

11. Drago F, Ranieri E, Malaguti F, Losi E, Rebora A (1997) Human herpesvirus 7 in pityriasis rosea. Lancet 349(9062):1367-1368.

12. Kempf W, Adams V, Kleinhans M, Burg G, Panizzon RG, et al. (1999) Pityriasis rosea is not associated with human herpesvirus 7. Arch Dermatol 135(9):1070-1072.

13. Yasukawa M, Sada E, MacHino H, Fujita S (1999) Reactivation of human herpesvirus 6 in pityriasis rosea. Br J Dermatol 140(1):169-170.

14. Karabulut AA, Koçak M, Yilmaz N, Eksioglu M (2002) Detection of human herpesvirus 7 in pityriasis rosea by nested PCR. Int J Dermatol 41(9):563-567.

\section{Your next submission with Juniper Publishers will reach you the below assets}

- Quality Editorial service

- Swift Peer Review

- Reprints availability

- E-prints Service

- Manuscript Podcast for convenient understanding

- Global attainment for your research

- Manuscript accessibility in different formats

( Pdf, E-pub, Full Text, Audio)

- Unceasing customer service

Track the below URL for one-step submission https://juniperpublishers.com/online-submission.php 